\title{
Biological behavior of magnesium-substituted hydroxyapatite during bone repair
}

\author{
G. G. Santos ${ }^{a, b}$ (D), V. L. C. Nunes ${ }^{c, d}$ (D), S. M. O. C. Marinho ${ }^{a}$ (D), S. R. A. Santos ${ }^{\text {(D), }}$ \\ A. M. Rossi i (D) and F. B. Miguel ${ }^{\text {* }}$ \\ a'Laboratório de Ciências e Tecnologias da Saúde - LaCTS, Centro de Ciências da Saúde - CCS, Universidade Federal do \\ Recôncavo da Bahia - UFRB, Av. Carlos Amaral, 1015, Cajueiro, CEP 44574-490, Santo Antônio de Jesus, BA, Brasil \\ ${ }^{b}$ Laboratório de Bioengenharia Tecidual e Biomateriais - LBTB, Instituto de Ciências da Saúde - ICS, Universidade \\ Federal da Bahia - UFBA, Av. Reitor Miguel Calmon, s/n, Vale do Canela, CEP 40110-100, Salvador, BA, Brasil \\ 'Faculdade de Medicina - FAMED, Universidade Federal da Bahia - UFBA, Av. Reitor Miguel Calmon, s/n, Canela, \\ CEP 40110-903, Salvador, BA, Brasil \\ ¿Escola Bahiana de Medicina e Saúde Pública - EBMSP, Av. Dom João VI, 275, Brotas, CEP 40290-000, Salvador, BA, Brasil \\ 'Laboratório de Biomateriais - LABIOMAT, Centro Brasileiro de Pesquisas Físicas - CBPF, Ministério da Ciência, \\ Tecnologia e Inovação - MCTI, Rua Dr. Xavier Sigaud, 150, Urca, CEP 22290-180, Rio de Janeiro, RJ, Brasil \\ *e-mail: fulviomiguel@yahoo.com.br
}

Received: December 14, 2018 - Accepted: October 27, 2019 - Distributed: February 28, 2021

(With 6 figures)

\begin{abstract}
The aim of this study was to analyze the biological behavior and osteogenic potential of magnesium $(\mathrm{Mg})$ substituted hydroxyapatite (HA) microspheres, implanted in a critical bone defect, considering that this ion is of great clinical interest, since it is closely associated with homeostasis and bone mineralization. For the purpose of this study, 30 rats were used to compose three experimental groups: GI - bone defect filled with HA microspheres; GII - bone defect filled with HA microspheres replaced with Mg; GIII - empty bone defect; evaluated at biological points of 15 and 45 days. The histological results, at 15 days, showed, in all the groups, a discrete chronic inflammatory infiltrate; biomaterials intact and surrounded by connective tissue; and bone neoformation restricted to the borders. At 45 days, in the GI and GII groups, an inflammatory response of discrete granulomatous chronic type was observed, and in the GIII there was a scarce presence of mononuclear inflammatory cells; in GI and GII, the microspheres were seen to be either intact or fragmented, surrounded by fibrous connective tissue rich in blood vessels; and discrete bone neoformation near the edges and surrounding some microspheres. In GIII, the mineralization was limited to the borders and the remaining area was filled by fibrous connective tissue. It was concluded that the biomaterials were biocompatible and osteoconductive, and the percentage of $\mathrm{Mg}$ used as replacement ion in the HA did not favor a greater bone neoformation in relation to the HA without the metal.
\end{abstract}

Keywords: hydroxyapatite, critical bone defect, magnesium, bone regeneration, rat.

\section{Comportamento biológico de hidroxiapatita substituída com magnésio durante o reparo ósseo}

\section{Resumo}

O objetivo deste estudo foi analisar o comportamento biológico de microesferas de hidroxiapatita (HA) substituída com magnésio $(\mathrm{Mg})$ durante o reparo de defeito ósseo crítico, tendo em vista que este íon é de grande interesse clínico, pois está intimamente associado à homeostasia e à mineralização óssea. Para tanto, utilizou-se 30 ratos para compor três grupos experimentais: GI - defeito ósseo preenchido com microesferas de HA; GII - defeito ósseo preenchido com microesferas de HA substituída com Mg; GIII (controle) - defeito ósseo vazio; avaliados nos pontos biológicos de 15 e 45 dias. Os resultados histológicos evidenciaram, aos 15 dias, discreto infiltrado inflamatório crônico e neoformação óssea restrita às bordas, em todos os grupos. Nos grupos GI e GII, os biomateriais mantiveram-se íntegros e circundados por tecido conjuntivo frouxo. Aos 45 dias, notou-se resposta inflamatória do tipo crônica granulomatosa discreta nos grupos GI e GII, e no GIII presença escassa de células inflamatórias mononucleares. As microesferas implantadas no GI e GII mantiveram-se, em sua maioria, íntegras e envolvidas por tecido conjuntivo fibroso. Notou-se discreta neoformação óssea próxima às bordas e circunjacente a algumas microesferas. No GIII, a mineralização limitou-se às bordas e a área remanescente foi preenchida por tecido conjuntivo fibroso. Conclui-se que os biomateriais foram biocompatíveis, bioativos, osteocondutores e apresentaram biodegradação lenta, indicando seu grande potencial para em aplicações clínica como biomaterial de preenchimento.

Palavras-chave: hidroxiapatita, defeito ósseo crítico, magnésio, regeneração óssea, rato. 


\section{Introduction}

The use of ceramic biomaterials, in order to replace and/or aid in the regeneration of bone tissue, has been documented for more than a century. Although this tissue is able to completely regenerate under physiological conditions, in the presence of extensive tissue losses repair occurs with the formation of fibrous connective tissue (Cardoso et al., 2006; Miguel et al., 2006, 2013). This, in most cases, compromises the function, aesthetics, labor and quality of life of the affected individuals.

Among the different types of ceramics used in bone regenerative techniques, calcium phosphates $(\mathrm{CaP})$ are part of the widely used group of materials, especially synthetic HA. This biomaterial is similar to components of the mineral phase of the bone tissue, biocompatible, bioactive, with excellent osteoconductivity and absence of local or systemic toxicity, and with no risk of disease transmission (Vallet-Regí and González-Calbet, 2004; Yuasa et al., 2004). Moreover, it serves as a framework for the cellular events that occurr during tissue regeneration, which make bone neoformation possible in association with its structure. Depending on the method used during the synthesis and processing of the materials, the HA may have a slow or rapid degradation rate, which will determine its clinical applications.

It is known that bone regeneration is a physiological mechanism that depends, among other factors, on the availability of some ions such as calcium (Ca), phosphorus $(\mathrm{P})$, fluorine $(\mathrm{F})$, zinc $(\mathrm{Zn})$ and $\mathrm{Mg}$. Some researchers have performed isomorphic substitutions in the hexagonal structure of synthetic HA through partial exchange of $\mathrm{Ca}$ by F, Zn, Sr or Mg (Cazalbou et al., 2005; Terra et al., 2009; Lima et al., 2011; Zilm et al., 2015; Geng et al., 2016; Ribeiro et al., 2016; Tao et al., 2016) in order to improve the physicochemical properties of this ceramic and, consequently, the biological response after implantation in vivo. Among these ions, $\mathrm{Mg}$ is of great clinical interest, since it is closely correlated with homeostasis and bone mineralization (Bigi et al., 1992, 1993; Bertoni et al., 1998; Gouveia et al., 2008; Jia et al., 2010; Laurencin et al., 2011; Nabiyouni et al., 2015; Tao et al., 2016).

These substitutions may alter crystallinity, solubility, network parameters, thermal stability, surface reactivity, bioactivity (Bigi et al., 1992, 1993; Bertoni et al., 1998; LeGeros, 2002; Gouveia et al., 2008; Terra et al., 2009; Laurencin et al., 2011; Tao et al., 2016), the adsorption properties of the HA (Bigi et al., 1992, 1993; Bertoni et al., 1998; Mavropoulos, 1999; Laurencin et al., 2011; Tao et al., 2016) and the biological behavior (Lima et al., 2011). Therefore, new studies are needed to evaluate these biomaterials with new physical-chemical characteristics. Thus, the objective of the present study was to analyze the biological behavior of $\mathrm{Mg}$-substituted HA microspheres, implanted in critical bone defect, in adult rat calvaria.

\section{Material and Methods}

\subsection{Biomaterials}

\subsubsection{Synthesis of HA and MgHA powders}

The biomaterials evaluated in this study were produced, characterized and supplied by the LABIOMAT researchers of the Brazilian Center for Physical Research (CBPF), Rio de Janeiro, Brazil. The powders were synthesized by wet precipitation method, under a synthesis temperature of $90{ }^{\circ} \mathrm{C}$ and $\mathrm{Ca} / \mathrm{P} \geq 1,67$ ratio. For the synthesis, solutions of Ca nitrate, $\mathrm{Mg}$ nitrate (molar contents of $1 \%$ ) and dibasic ammonium phosphate were used. The solution of metals was dripped into the solution of phosphorus ions (P) and the reaction conditions were maintained throughout the process. The material obtained was filtered and washed until $\mathrm{pH} 7.0$, in wash water. The solids were oven dried at $100{ }^{\circ} \mathrm{C}$ for $24 \mathrm{~h}$. Finally, the solid was macerated and separated using sieve with an aperture of $<74 \mu \mathrm{m}$ mesh.

\subsubsection{Processing of HA and MgHA microspheres}

The HA powders substituted with $1 \%$ by mass of $\mathrm{Mg}$ (MgHA) and without substitution (HA), obtained in the previous step $(<74 \mu \mathrm{m})$, were mixed into a solution of $1 \% \mathrm{wt} . / \mathrm{v}$ sodium alginate until a ceramic slurry was formed. By extrusion, this slurry was dripped into a solution of $\mathrm{Ca}$ chloride $\left(\mathrm{CaCl}_{2}\right)$ to form the microspheres which, after 24 hours, were washed and oven dried at $70^{\circ} \mathrm{C}$. After this step, the biomaterial was sintered in a heating ramp to a temperature of $1000^{\circ} \mathrm{C}$ in a muffle furnace. The obtained microspheres were separated in the granulometric range of $425>\phi<600 \mu \mathrm{m}$ and aliquoted in Eppendorf tubes for autoclave sterilization.

\subsubsection{Physical-chemical characterization of HA and MgHA powders}

\subsubsection{Superficial area}

The superficial area of the powders was analyzed by BET method (Micromeritics ${ }^{\circledR}-$ ASAP2010) (Table 1).

\subsubsection{Chemical analysis}

$\mathrm{X}$-ray fluorescence (XRF) was performed to determine the HA stoichiometry, particularly the $\mathrm{Mg} / \mathrm{Ca}$ molar ratio and calcium substitutions (Table 2). This analysis was performed through X-ray fluorescence spectrometer (Philips ${ }^{\circledR}-$ PW2400).

\subsubsection{X-ray diffraction (X-RD) of $\mathrm{HA}$ and $\mathrm{MgHA}$}

The X-ray diffraction was performed on the high resolution diffractometer (Zeiss ${ }^{\circledR}-$ HZG4) operating at $30 \mathrm{kV}$ and $15 \mathrm{~mA}$ with $\mathrm{CuK} \alpha$ radiation $(\lambda=1.542 \AA)$. The data was collected in the $2 \theta$ range of $10-80^{\circ}$ with

Table 1. Surface area of HA and MgHA powders, BET method.

\begin{tabular}{cc}
\hline Biomaterial & Surface area $\mathbf{~ m}^{2} / \mathbf{g}$ \\
\hline HA & 3,445 \\
MgHA & 2.283 \\
\hline
\end{tabular}


Table 2. Chemical analysis of HA and MgHA powders, values obtained by the average of the three samples.

\begin{tabular}{cccccccc}
\hline Sample & $\mathbf{C a} \%$ & $\mathbf{m o l}$ of $\mathbf{C a}$ & $\mathbf{P} \%$ & $\mathbf{m o l}$ of $\mathbf{P}$ & $\mathbf{C a} / \mathbf{P}$ & $\begin{array}{c}\text { Metal \% } \\
\mathbf{( M g})\end{array}$ & $\begin{array}{c}\text { mol of } \\
\text { Metal }\end{array}$ \\
\hline HA & 37.0 & 0.92319976 & 17.10 & 0.55315211 & 1.67 & ----- & ----- \\
MgHA & 37.3 & 0.93151688 & 17.08 & 0.55153785 & 1.70 & 0.47 & 0.005402 \\
\hline
\end{tabular}

a step of $0.05^{\circ}$ point per second, for 160 seconds. The spectra obtained was compared with those present in the standard sheet PCPDFWIN 09.0432 of the database (JCPDS - Joint Committee on Powder Diffraction Standards) (Figure 1).

2.1.5. Fourier Transform Infrared Spectroscopy (FTIR) of $\mathrm{HA}$ and $\mathrm{MgHA}$

Infrared analysis was performed on the Fourier Transform Infrared Spectrophotometer (Schimadzu ${ }^{\circledR}$-IR-Prestige 21) with $\mathrm{KBr}$ Beam Separator. The analysis was done by transmittance using $1 \% \mathrm{KBr}$ pellet in the median infrared region $\left(400-4000 \mathrm{~cm}^{-1}\right)$ (Figure 2).

\subsection{Ethical considerations}

The experimental procedures of this study were carried out in the Central Biotério of the State University of Feira de Santana (UEFS) in accordance with the Ethical Norms for Research on Animals (Law No. 11.794 of 2008), after approval by the Ethics Committee on Animal Use (CEUA) of this institution, protocol 004/2011.

\subsection{Sample}

30 adult male Wistar rats, weighing between 350 and $450 \mathrm{~g}$, were randomly assigned to three experimental groups with five animals at each biological point: GI - bone defect filled with HA microspheres; GII - bone defect filled with Mg-substituted HA (MgHA) microspheres; GIII (control) - empty bone defect, evaluated at biological points of 15 and 45 days (Table 3 ).

\subsection{Surgical experimental procedures}

Prior to the surgical procedure, the animals received analgesia, sedation and anesthesia in a single dose, by intramuscular injection of ketamine hydrochloride, at a ratio of $0.08 \mathrm{~mL} / 100 \mathrm{~g}$ body weight and $2 \%$ xylazine hydrochloride at a ratio of $0.04 \mathrm{~mL} / 100 \mathrm{~g}$ body weight. The animals were then placed in a prone position, trichotomized in the calvaria and submitted to surgical field antisepsis with chlorhexidine (1\%). The surgical technique used in the manufacture of the critical bone defect in rat calvaria was the same as described in Cardoso et al. (2006) and in Miguel et al. (2006). After the creation of the bone defect, the biomaterials were implanted, according to the experimental group. The tissue flap was then repositioned and sutured with interrupted stitches. In the animals of group GIII, the bone defects remained without implantation of microspheres. Throughout the experiment the animals received rat food and water ad libitum, in a fountain appropriate for rats.

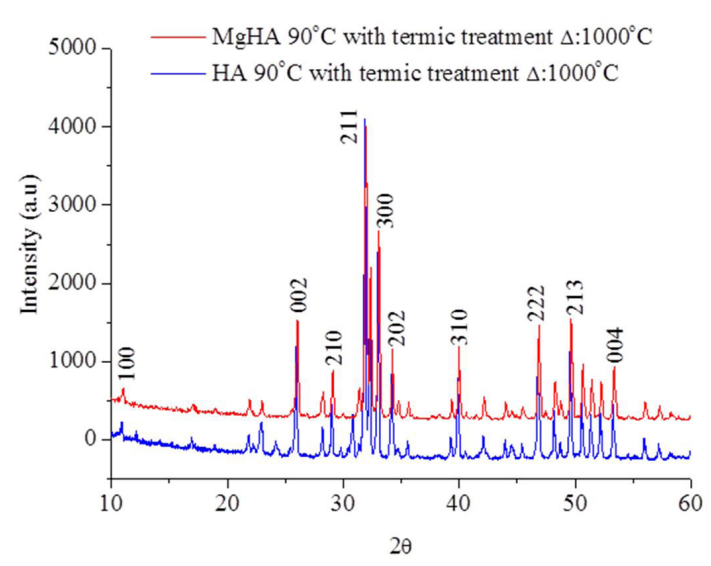

Figure 1. X-ray diffraction (X-RD) of HA and MgHA. It is noted that the HA has a slightly narrower base of the major peaks in relation to MgHA, evidence for the greater crystallinity of the material.

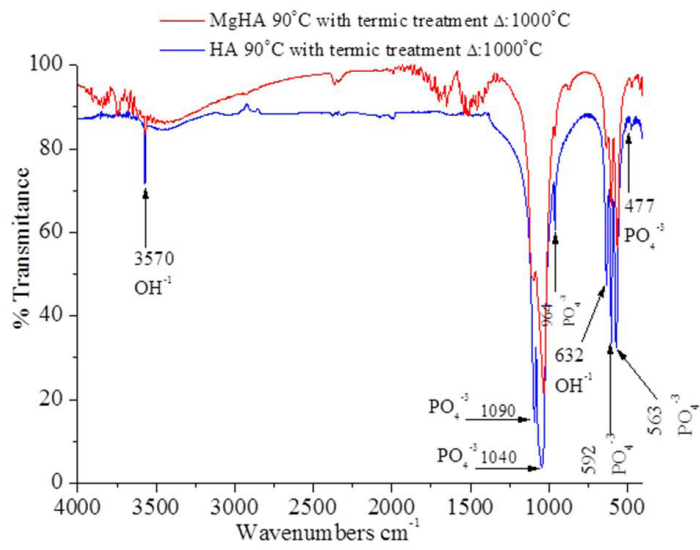

Figure 2. Fourier Transform Infrared Spectroscopy (FTIR) of $\mathrm{HA}$ and MgHA. It is observed that the spectra revealed characteristic bands of $\mathrm{HA}$ for phosphate $\left(\mathrm{PO}_{4}^{3-}\right)$, water $\left(\mathrm{H}_{2} \mathrm{O}\right)$ and hydroxyl $\left(\mathrm{OH}^{1-}\right)$, even for the material substituted with $\mathrm{Mg}$.

Table 3. Number of animals according to the experimental groups and biological points.

\begin{tabular}{lcc}
\hline $\begin{array}{c}\text { Experimental } \\
\text { Group }\end{array}$ & \multicolumn{2}{c}{$\begin{array}{c}\text { Number of animals } \\
\text { per biological point }\end{array}$} \\
\cline { 2 - 3 } & $\mathbf{1 5}$ days & $\mathbf{4 5}$ days \\
\hline GI (HA) & 5 & 5 \\
GII (MgHA) & 5 & 5 \\
GIII (Control) & 5 & 5 \\
& Total & $\mathbf{3 0}$ \\
\hline
\end{tabular}




\subsection{Histological processing and histomorphological analysis}

After the euthanasia of the animals, at the biological points of 15 and 45 days, the upper portion of the calvaria was removed, reduced in lateral-posterior, posterior and anterior portions, discarding all the surrounding soft tissue. The specimens were then fixed in $4 \%$ formaldehyde for 48 hours. After this step, the samples were decalcified in $7 \%$ nitric acid, for two hours, under technical supervision, and embedded in paraffin. The serial histological sections of $5 \mu \mathrm{m}$ thickness were stained with hematoxylin-eosin (HE) and examined by light microscopy.

\section{Histological Results}

At 15 days, the histomorphological analysis showed discrete chronic inflammation in all three groups. In GI and GII the microspheres remained intact, permeated by cells and surrounded by loose connective tissue. Bone neoformation was noted in the three experimental groups, near the edges of the bone defect. In the GI, some nuclei mineralization was observed adjacent to the microspheres in the region near the center of the defect. In GII, this finding was more evident near the bone edges. In GIII, the remaining area was filled by loose connective tissue (Figures 3 and 4).

At 45 days, discrete chronic inflammation was observed in all three groups. In GI and GII, this inflammation was of the chronic granulomatous type. In the GIII, the scarce presence of mononuclear inflammatory cells was noticed. Most microspheres remained intact, acellular and enveloped by a loose connective tissue denser than the previous period, both in GI and GII. In these two groups, the bone neoformation near the edges was notorious and more evident than in the GIII, in which the mineralization remained similar to that seen at the biological point of 15 days. In the central region of the defect, similarly in GI and GII, a larger amount of newly formed mineralized tissue was observed around the microspheres compared to the previous period (Figures 5 and 6).

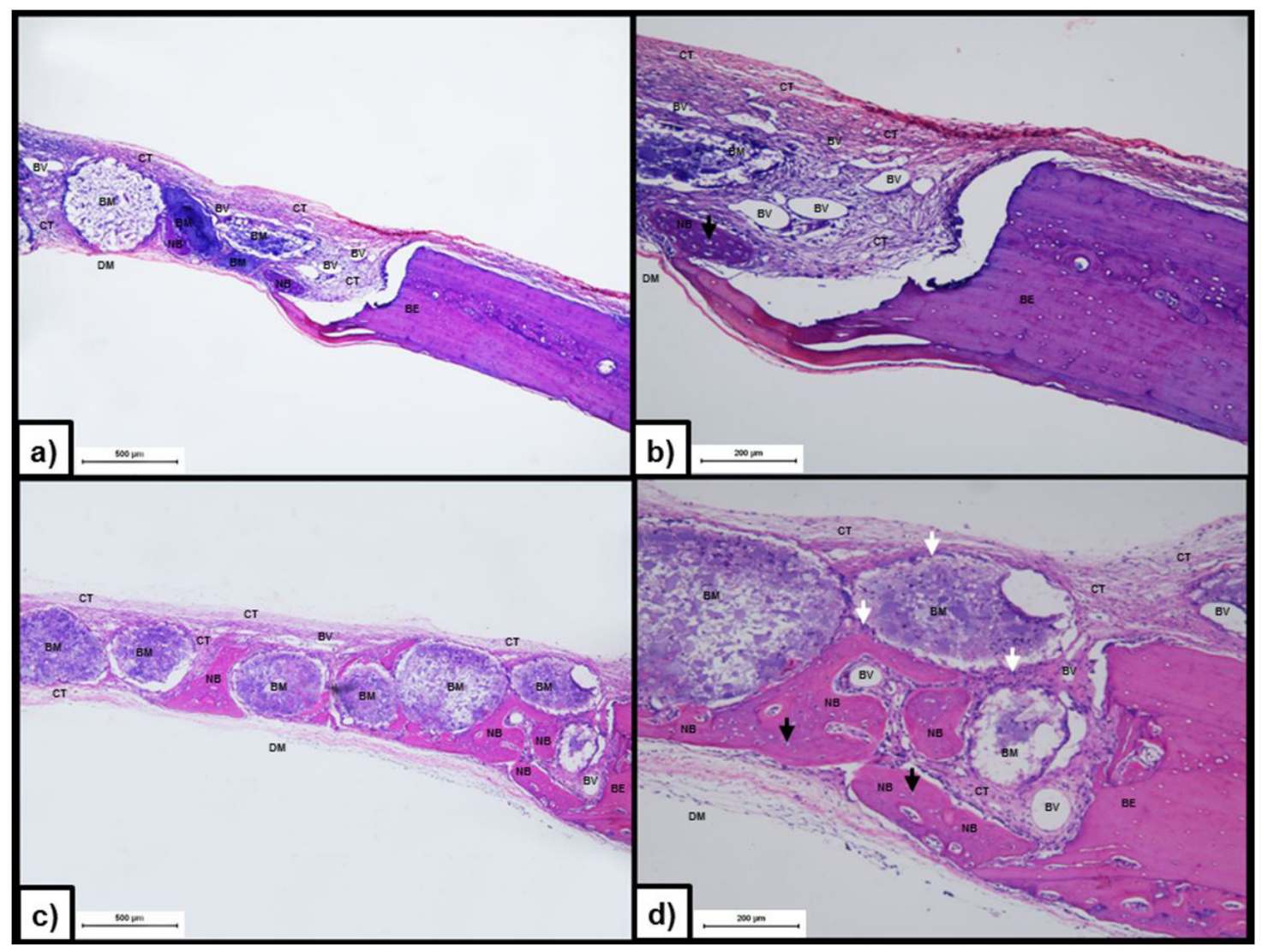

Figure 3. Photomicrographs of bone edge region after 15 days. Note the presence of new formed bone (NB) surrounding the biomaterial $(\mathrm{BM})$ microsphere from the bone edge (BE) to the center of the bone defect. Blood vessels (BV) are seen within the neoformed connective tissue (CT). Dura-mater region (DM), osteocytes (black arrows), inflammatory cells (white arrows). (a) GI, Final enlargement $\times 4$; (b) GI, Final enlargement $\times 10$; (c) GII Final enlargement $\times 4$; (d) GII, Final enlargement $\times 10$. HE. 15 days. 


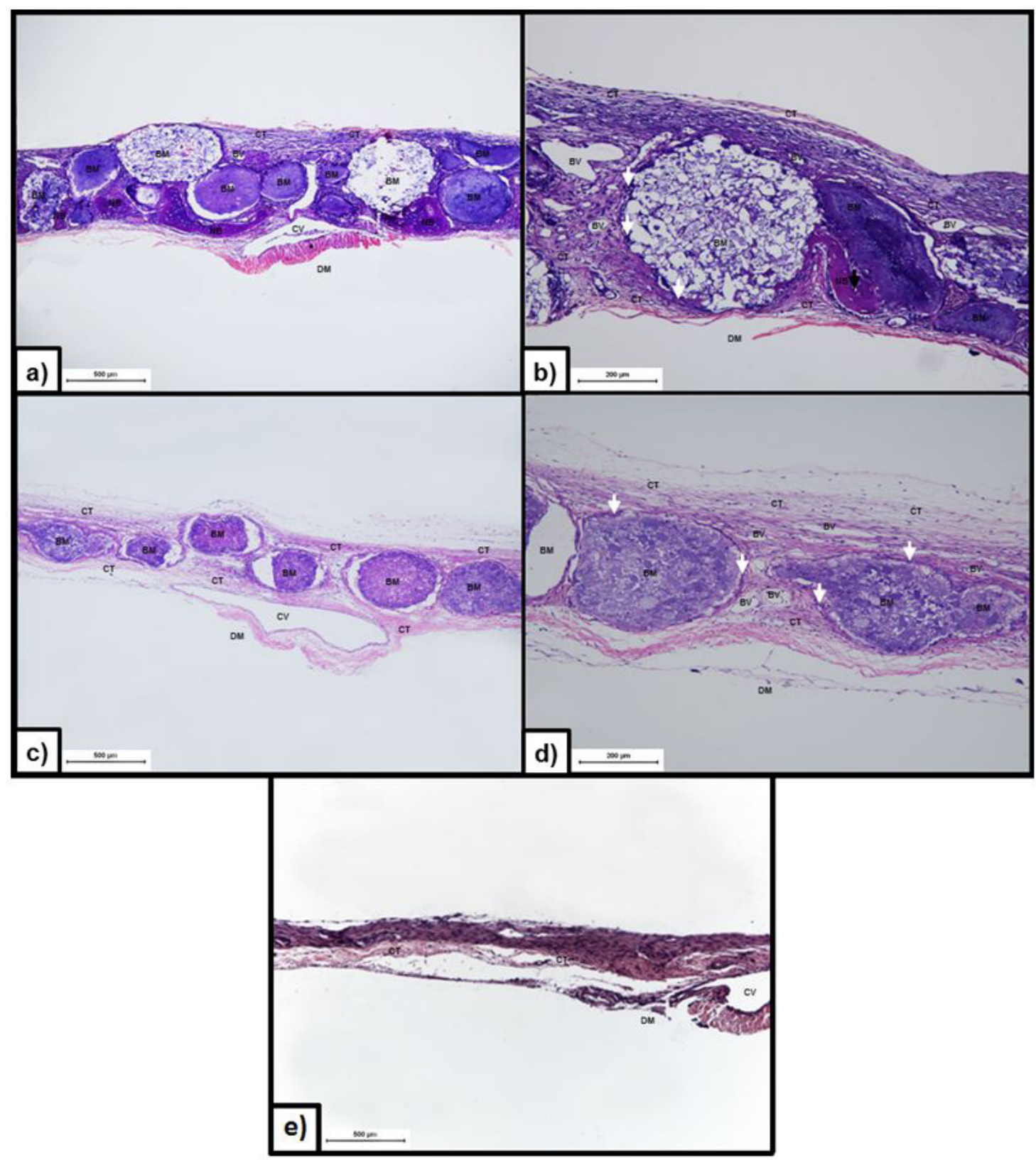

Figure 4. Photomicrographs of central region after 15 days. Note the presence of connective tissue (CT) with lots of blood vessels (BV) surrounding the biomaterial (BM) microsphere that remained intact at the central region of the bone defect. Most of biomaterial microspheres (BM). Scarce new formed bone (NB) was observed. Dura-mater region (DM), osteocytes (black arrows), inflammatory cells (white arrows). (a) GI, Final enlargement $\times 4$; (b) GI, Final enlargement $\times 10$; (c) GII Final enlargement $\times 4$; (d) GII, Final enlargement $\times 10$; (e) GIII, Final enlargement $\times 4$. HE. 15 days.

\section{Discussion}

Bone regeneration is a mechanism of tissue repair that depends, among other factors, on adequate blood supply, mechanical stability, size of lesion, availability of minerals, vitamins and trace elements, such as $\mathrm{F}, \mathrm{Zn}, \mathrm{Sr}$ and $\mathrm{Mg}$, which are essential for mineralization (Hill and Orth, 1998; Nabiyouni et al., 2015; Geng et al., 2016; Tao et al., 2016). Taking this into consideration, some researchers have mimicked the biological apatite and performed ionic substitutions in the structure of the synthetic HA to alter its physicochemical properties and optimize the biological response, considering that this ceramic presents low rate of biodegradation in vivo (Ribeiro et al., 2016; Geng et al., 2016). Thus, in the present study the biological behavior and the osteogenic potential of Mg-substituted HA microspheres after implantation in a critical bone defect in rat calvaria was analyzed. 


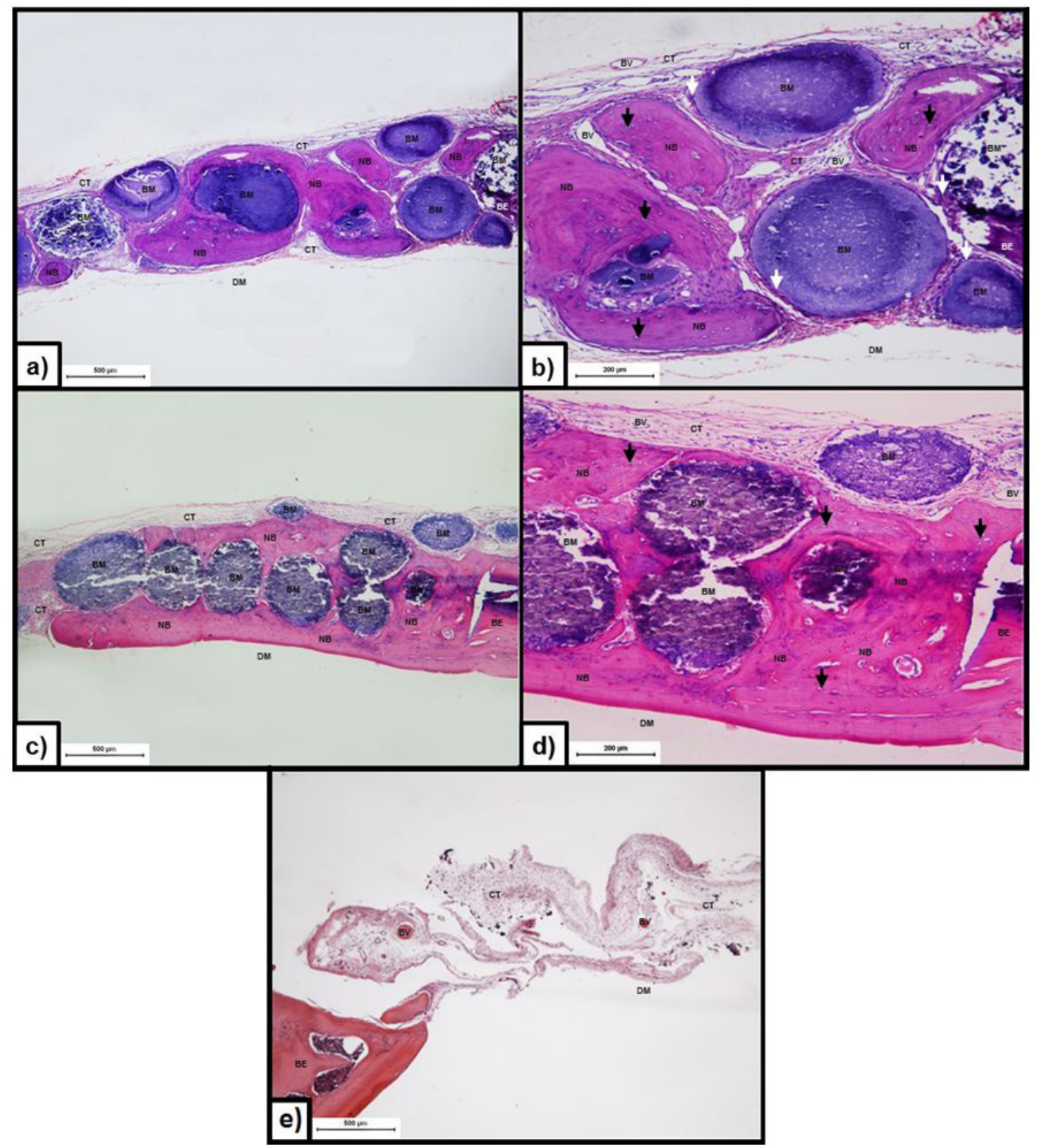

Figure 5. Photomicrographs of bone edge region after 45 days. Note the presence of abundant new formed bone (NB) surrounding the partially fragmented biomaterial (BM) microsphere from the bone edge (BE) to the center of the bone defect. Many osteocytes (black arrows) within the NB matrix. Blood vessel (BV), connective tissue (CT), dura-mater region (DM), inflammatory cells (white arrows). (a) GI, Final enlargement $\times 4$; (b) GI, Final enlargement $\times 10$; (c) GII Final enlargement $\times 4$; (d) GII, Final enlargement $\times 10$; (e) GIII, Final enlargement $\times 4$. HE. 45 days.

The creation of critical bone defect results in vascular rupture, leakage of blood cells, clot formation and release of inflammatory cytokines which trigger a chronic inflammatory response (Anderson et al., 2008), as observed in the histological results of the three experimental groups of our study, at 15 days (Cardoso et al., 2006; Miguel et al., 2006; Almeida et al., 2015; Ribeiro et al., 2015). At 45 days, in groups I and II the response was of a discrete granulomatous chronic type, characteristics of the foreign body reaction observed after the implantation of biomaterials (Anderson et al., 2008). These results were also seen by Miguel et al. (2013) and Costa et al. (2016), although these authors have evaluated other types of biomaterials. The absence of rejection by the organism shows that both biomaterials were similarly biocompatible.

In our study, the distribution of the microspheres along the bone defect in both implanted groups, both at 15 and 45 days, provided the three-dimensional (3D) 


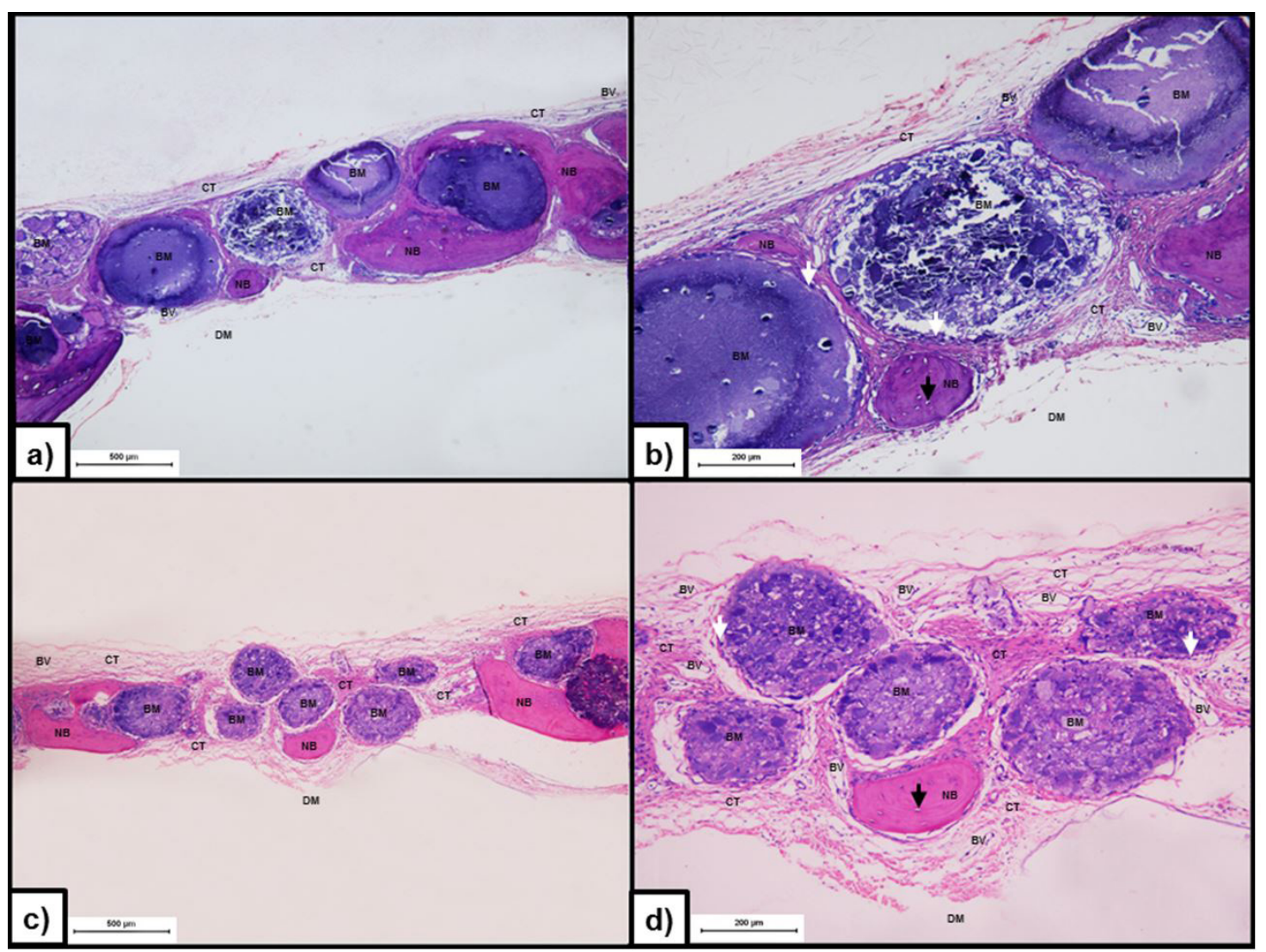

Figure 6. Photomicrographs of central region after 45 days. Note the presence of new formed bone (NB) and connective tissue (CT) with blood vessels (BV) surrounding the intact biomaterial (BM) microsphere at the central region of bone defect. Dura-mater region (DM), osteocytes (black arrows), inflammatory cells (white arrows). (a) GI, Final enlargement $\times 4$; (b) GI, Final enlargement $\times 10$; (c) GII Final enlargement $\times 4$; (d) GII, Final enlargement $\times 10$. HE. 45 days.

framework essential for cell migration and proliferation, angiogenesis and osteogenesis, fundamental to bone regeneration (Venkatesan et al., 2015). Therefore, the observed tissue formation surrounding and permeating the microspheres was evident and presented thickness proportional to bone edges. On the other hand, the absence of a framework in GIII limited the aforementioned events and resulted in the formation of connective tissue with reduced thickness in relation to the bone edges, mainly in the central region of the defect, at 45 days. Consequently, in this group, the new bone formation was restricted to the borders, throughout the study (Cardoso et al., 2006; Miguel et al., 2006, 2013; Tovar et al., 2014; Costa et al., 2016).

Bone neoformation was observed, in a similar way in groups I and II, beyond the borders, in the centripetal direction, in and around the microspheres. This suggests that the incorporation of $\mathrm{Mg}$ into the HA structure did not favor a greater osteogenic potential to the biomaterial, corroborating with the findings of Yassuda et al. (2013), which evaluated $\beta$-tricalcium phosphate $(\beta$-TCP) substituted with $\mathrm{Mg}$ in rats, and Sartori et al. (2014) who evaluated Mg-substituted HA in sheep, both in critical bone defect.
Some studies suggest that $\mathrm{Mg}$ inhibits the formation of amorphous $\mathrm{CaP}$ within the synthetic HA structure given the introduction of distorted solid structures and the structural lag resulting from inhibition of crystal growth (Bigi et al., 1992, 1993; Bertoni et al., 1998; Laurencin et al., 2011). It is emphasized that the amorphous phase of $\mathrm{CaP}$ represents the beginning of the mineralization, which occurs in the gap regions of the collagen fibril and extends parallel to the fibrils, in the inter fiber spaces of the collagen fiber (Chae et al., 2013; Nabiyouni et al., 2015).

The increase in the amount of imperfect crystals and the reduction of crystal size increases the rate of biodegradation of the ceramics (Lu et al., 2002). According to Azevedo et al. (2014) this decrease in crystal size average may be correlated with the decomposition of HA crystals into Tricalcium Phosphate (TCP).

Some studies have shown that $\mathrm{Mg}$ can induce the conversion of HA to $\mathrm{Mg}$-containing $\beta$-tricalcium phosphate $\left(\beta\right.$-TCMP) during the heat treatment at $1000^{\circ} \mathrm{C}$ (Bigi et al., 1992, 1993; Bertoni et al., 1998; Laurencin et al., 2011). However, this depends on the percentage of $\mathrm{Mg}$ present in the HA structure, given that at $5 \%$ and $10 \% \mathrm{Mg}$, this conversion started at $700{ }^{\circ} \mathrm{C}$ and at $1 \% \mathrm{Mg}$ at $900{ }^{\circ} \mathrm{C}$. In the latter case, the percentage of HA and $\beta$-TCMP is 
approximately $90 \%$ and $5 \%$, respectively. This occurs similarly with HA without Mg (Bertoni et al., 1998). The MgHA evaluated in our study showed, in the XRF analysis, a concentration of $0.47 \% \mathrm{Mg}, 79 \%$ HA phase and $21 \% \beta$-TCMP, and, nonetheless, the microspheres remained mostly intact at the end of the study, and did not present notorious biodegradation, in consonance with the results found by Yassuda et al. (2013) and Sartori et al. (2014), showing that the presence of Mg makes the ceramic biomaterials less bioresorbable, even in reduced concentrations. The microspheres implanted in GI showed a profile of biodegradation similar to GII, even without the presence of the metal. This can be justified by the high crystallinity of these biomaterials (Figure 1). It is worth noting that the materials evaluated in our study (GI and GII) were sintered, a biomaterial processing pathway that favors the fusion of the HA crystals and hinders biodegradation (Bigi et al., 1992, 1993; Bertoni et al., 1998; Laurencin et al., 2011; Xiao et al., 2016).

The results of the present study showed that the percentage of $\mathrm{Mg}$ used did not favor a greater bone neoformation in relation to HA without the metal. Therefore, new studies need to be developed in order to evaluate the efficacy of other $\mathrm{Mg}$ percentages and their influence on the biodegradation and biological behavior of the new materials.

\section{Conclusion}

The biomaterials were biocompatible and osteoconductive, making them promising for use as fillers. Both biomaterials showed similar biodegradation throughout the experiment. The percentage of $\mathrm{Mg}$ evaluated did not increase the osteogenic potential of the biomaterials.

\section{Acknowledgements}

The authors and researchers involved in this study thank the Foundation for Fundação de Amparo à Pesquisa do Estado da Bahia (FAPESB) for the financial support for this project (Project PPP0053/2011).

\section{References}

ALMEIDA, R.S., RIBEIRO, I.I.A., PRADO DA SILVA, M.H., ROCHA, D.N., MIGUEL, F.B. and ROSA, F.P., 2015. Avaliação da fase inicial do reparo ósseo após implantação de biomateriais. Revista de Ciências Médicas e Biológicas, vol. 13, no. 3, pp. 331336. http://dx.doi.org/10.9771/cmbio.v13i3.12940.

ANDERSON, J.M., RODRIGUEZ, A. and CHANG, D.T., 2008. Foreign body reaction to biomaterials. Seminars in Immunology, vol. 20, no. 2, pp. 86-100. http://dx.doi.org/10.1016/j.smim.2007.11.004. PMid:18162407.

AZEVEDO, A.G.S., STRECKER, K. and ARAÚJO JÚNIOR, A.G., 2014. Avaliação da influência da razão Ca/P nos valores de cristalinidade e crescimento de cristais durante a sinterização de pós de hidroxiapatita. Revista Eletrônica de Materiais e Processos, vol. 9, no. 3, pp. 125-129.
BERTONI, E., BIGI, A., COJAZZI, G., GANDOLFI, M., PANZAVOLTA, S. and ROVERI, N.O., 1998. Nanocrystals of magnesium and fluoride substituted hydroxyapatite. Journal of Inorganic Biochemistry, vol. 72, no. 1-2, pp. 29-35. http://dx.doi. org/10.1016/S0162-0134(98)10058-2. PMid:9861727.

BIGI, A., FALINI, G., FORESTI, E., RIPAMONTI, A., GAZZANO, M. and ROVERI, N., 1993. Magnesium influence on hydroxyapatite crystallization. Journal of Inorganic Biochemistry, vol. 49, no. 1, pp. 69-78. http://dx.doi.org/10.1016/0162-0134(93)80049-F.

BIGI, A., FORESTI, E., GREGORINI, R., RIPAMONTI, A., ROVERI, N. and SHAH, J.S., 1992. The role of magnesium on the structure of biological apatites. Calcified Tissue International, vol. 50, no. 5, pp. 439-444. http://dx.doi.org/10.1007/BF00296775. PMid:1596779.

CARDOSO, A.K.M.V., BARBOSA JÚNIOR, A.A., MIGUEL, F.B., MARCANTONIO JÚNIOR, E., FARINA, M., SOARES, G.D. and ROSA, F.P., 2006. Histomorphometric analysis of tissue responses to bioactive glass implants in critical defects in rat calvaria. Cells, Tissues, Organs, vol. 184, no. 3-4, pp. 128-137. http://dx.doi.org/10.1159/000099619. PMid:17409738.

CAZALBOU, S., EICHERT, D., RANZ, X., DROUET, C., COMBES, C., HARMAND, M.F. and REY, C., 2005. Ion exchanges in apatites for biomedical applications. Journal of Materials Science: Materials in Medicine, vol. 16, no. 5, pp. 405-409. http://dx.doi.org/10.1007/s10856-005-6979-2. PMid:15875249.

CHAE, T., YANG, H., LEUNG, V., KO, F. and TROCZYNSKI, T., 2013. Novel biomimetic hydroxyapatite/alginate nanocomposite fibrous scaffolds for bone tissue regeneration. Journal of Materials Science: Materials in Medicine, vol. 24, no. 8, pp. 1885-1894. http://dx.doi.org/10.1007/s10856-013-4957-7. PMid:23695359.

COSTA, N.M., YASSUDA, D.H., SADER, M.S., FERNANDES, G.V., SOARES, G.D. and GRANJEIRO, J.M., 2016. Osteogenic effect of tricalcium phosphate substituted by magnesium associated with Genderm ${ }^{\circledast}$ membrane in rat calvarial defect model. Materials Science and Engineering C, vol. 61, no. 1, pp. 63-71. http://dx.doi. org/10.1016/j.msec.2015.12.003. PMid:26838825.

GENG, Z., WANG, R., LI, Z., CUI, Z., ZHU, S., LIANG, Y., LIU, Y., HUIJING, B., LI, X., HUO, Q., LIU, Z. and YANG, X., 2016. Synthesis, characterization and biological evaluation of strontium/magnesium-co-substituted hydroxyapatite. Journal of Biomaterials Applications, vol. 31, no. 1, pp. 140-151. http:// dx.doi.org/10.1177/0885328216633892. PMid:26916949.

GOUVEIA, D.S., COUTINHO, A.C.S., BRESSIANI, A.H.A. and BRESSIANI, J.C., 2008. Effect of Mg2+ addition during HA nanoparticles synthesis using ultrasonic irradiation. Key Engineering Materials, vol. 361-63, pp. 203-206.

HILL, P.A. and ORTH, M., 1998. Bone remodelling. British Journal of Orthodontics, vol. 25, no. 2, pp. 101-107. http://dx.doi. org/10.1093/ortho/25.2.101. PMid:9668992.

JIA, J., ZHOU, H., WEI, J., JIANG, X., HUA, H., CHEN, F., WEI, S., SHIN, J.W. and LIU, C., 2010. Development of magnesium calcium phosphate biocement for bone regeneration. Journal of the Royal Society, Interface, vol. 7, no. 49, pp. 1171-1180. http:// dx.doi.org/10.1098/rsif.2009.0559. PMid:20181560.

LAURENCIN, D., ALMORA-BARRIOS, N., DE LEEUW, N.H., GERVAIS, C., BONHOMME, C., MAURI, F., CHRZANOWSKI, W., KNOWLES, J.C., NEWPORT, R.J., WONG, A., GAN, Z. and SMITH, M.E., 2011. Magnesium incorporation into hydroxyapatite. Biomaterials, vol. 32, no. 7, pp. 1826-1837. http:// dx.doi.org/10.1016/j.biomaterials.2010.11.017. PMid:21144581. 
LEGEROS, R.Z., 2002. Properties of osteoconductive biomaterials: calcium phosphates. Clinical Orthopaedics and Related Research, vol. 395, pp. 81-98. http://dx.doi.org/10.1097/00003086-20020200000009. PMid: 11937868.

LIMA, I.R., ALVES, G.G., SORIANO, C.A., CAMPANELI, A.P., GASPAROTO, T.H., RAMOS JUNIOR, E.S., DE SENA, L.Á., ROSSI, A.M. and GRANJEIRO, J.M., 2011. Understanding the impact of divalent cation substitution on hydroxyapatite: an in vitro multiparametric study on biocompatibility. Journal of Biomedical Materials Research Part A, vol. 98, no. 3, pp. 351358. http://dx.doi.org/10.1002/jbm.a.33126. PMid:21626666.

LU, J., DESCAMPS, M., DEJOU, J., KOUBI, G., HARDOUIN, P., LEMAITRE, J. and PROUST, J.P., 2002. The biodegradation mechanism of calcium phosphate biomaterials in bone. Journal of Biomedical Materials Research, vol. 63, no. 4, pp. 408-412. http://dx.doi.org/10.1002/jbm.10259. PMid:12115748.

MAVROPOULOS, E., 1999. A hidroxiapatita como absorvedor de metais. Rio de Janeiro: Escola Nacional de Saúde Pública, Fundação Oswaldo Cruz, 105 p. Dissertação de Mestrado em Saúde Pública.

MigUEL, F.B., BARBOSA JÚNIOR, A.A., PAULA, F.L., BARRETO, I.C., GOISSIS, G. and ROSA, F.P., 2013. Regeneration of critical bone defects with anionic collagen matrix as scaffolds. Journal of Materials Science. Materials in Medicine, vol. 24, no. 11, pp. 2567-2575. http://dx.doi.org/10.1007/s10856-013-4980-8. PMid:23784007.

MIGUEL, F.B., CARDOSO, A.K.M.V., BARBOSA JÚNIOR, A.A., MARCANTONIO JÚNIOR, E., GOISSIS, G. and ROSA, F.P., 2006. Morphological assessment of the behavior of threedimensional anionic collagen matrices in bone regeneration in rats. J. Journal of Biomedical Materials Research. Part B, Applied Biomaterials, vol. 78B, no. 2, pp. 334-339. http://dx.doi. org/10.1002/jbm.b.30492. PMid:16470816.

NABIYOUNI, M., REN, Y. and BHADURI, S.B., 2015. Magnesium substitution in the structure of orthopedic nanoparticles: a comparison between amorphous magnesium phosphates, calcium magnesium phosphates, and hydroxyapatites. Materials Science and Engineering C, vol. 52, pp. 11-17. http://dx.doi.org/10.1016/j. msec.2015.03.032. PMid:25953534.

RIBEIRO, I.Í.D.A., ALMEIDA, R.D.S., ROCHA, D.N., SILVA, M.H.P., MIGUEL, F.B. and ROSA, F.P., 2015. Biocerâmicas e polímero para a regeneração de defeitos ósseos críticos. Revista de Ciências Médicas e Biológicas, vol. 13, no. 3, pp. 298-302. http://dx.doi.org/10.9771/cmbio.v13i3.12934.

RIBEIRO, S., SARTORETTO, S.C., RESENDE, R., UZEDA, M., ALVES, A.T., SANTOS, S.A., PESCE, G., ROSSI, A.M., GRANJEIRO, J.M., MIGUEL, F. and CALASANS-MAIA, M.D., 2016. In vivo evaluation of Zinc-containing nanostructured carbonated hydroxyapatite. Key Engineering Materials, vol. 696, pp. 223-229. http://dx.doi.org/10.4028/www.scientific.net/ KEM.696.223.

SARTORI, M., GIAVARESI, G., TSCHON, M., MARTINI, L., DOLCINI, L., FIORINI, M., PRESSATO, D. and FINI, M., 2014.
Long-term in vivo experimental investigations on magnesium doped hydroxyapatite bone substitutes. Journal of Materials Science. Materials in Medicine, vol. 25, no. 6, pp. 1495-1504. http://dx.doi.org/10.1007/s10856-014-5177-5. PMid:24554305.

TAO, Z.S., ZHOU, W.S., HE, X.W., LIU, W., BAI, B.L., ZHOU, Q., HUANG, Z.L., TU, K.K., LI, H., SUN, T., LV, Y.X., CUI, W. and YANG, L., 2016. A comparative study of zinc, magnesium, strontium-incorporated hydroxyapatite-coated titanium implants for osseointegration of osteopenic rats. Materials Science and Engineering C, vol. 62, pp. 226-232. http://dx.doi.org/10.1016/j. msec.2016.01.034. PMid:26952418.

TERRA, J., DOURADO, E.R., EON, J.-G., ELLIS, D.E., GONZALEZ, G. and ROSSI, A.M., 2009. The structure of strontium-doped hydroxyapatite: an experimental and theoretical study. Physical Chemistry Chemical Physics, vol. 11, no. 3, pp. 568-577. http://dx.doi.org/10.1039/B802841A. PMid:19283275.

TOVAR, N., JIMBO, R., GANGOLLI, R., PEREZ, L., MANNE, L., YOO, D., LORENZONI, F., WITEK, L. and COELHO, P.G., 2014. Evaluation of bone response to various anorganic bovine bone xenografts: an experimental calvaria defect study. International Journal of Oral and Maxillofacial Surgery, vol. 43, no. 2, pp. 251-260. http://dx.doi.org/10.1016/j.ijom.2013.07.005. PMid:23948358.

VALLET-REGÍ, M. and GONZÁLEZ-CALBET, J.M., 2004. Calcium phosphates as substitution of bone tissues. Progress in Solid State Chemistry, vol. 32, no. 1-2, pp. 1-31. http://dx.doi. org/10.1016/j.progsolidstchem.2004.07.001.

VENKATESAN, J., BHATNAGAR, I., MANIVASAGAN, P., KANG, K.H. and KIM, S.K., 2015. Alginate composites for bone tissue engineering: a review. International Journal of Biological Macromolecules, vol. 72, pp. 269-281. http://dx.doi.org/10.1016/j. ijbiomac.2014.07.008. PMid:25020082.

XIAO, W., SONNY BAL, B. and RAHAMAN, M.N., 2016. Preparation of resorbable carbonate-substituted hollow hydroxyapatite microspheres and their evaluation in osseous defects in vivo. Materials Science and Engineering C, vol. 60, pp. 324-332. http://dx.doi.org/10.1016/j.msec.2015.11.039. PMid:26706537.

YASSUDA, D.H., COSTA, N.F.M., FERNANDES, G.O., ALVES, G.G., GRANJEIRO, J.M. and SOARES, G.A., 2013. Magnesium incorporation into $\beta$-TCP reduced its in vivo resorption by decreasing parathormone production. Journal of Biomedical Materials Research Part A, vol. 101A, no. 7, pp. 1986-1993. http://dx.doi.org/10.1002/jbm.a.34502. PMid:23239606.

YUASA, T., MIYAMOTO, Y., ISHIKAWA, K., TAKECHI, M., MOMOTA, Y., TATEHARA, S. and NAGAYAMA, M., 2004. Effects of apatite cements on proliferation and differentiation of human osteoblasts in vitro. Biomaterials, vol. 25, no. 7-8, pp. 1159-1166. http://dx.doi.org/10.1016/j.biomaterials.2003.08.003. PMid:14643589.

ZILM, M., THOMSON, S.D. and WEI, A.M., 2015. A comparative study of the sintering behavior of pure and manganese-substituted hydroxyapatite. Materials, vol. 8, no. 9, pp. 6419-6436. http:// dx.doi.org/10.3390/ma8095308. PMid:28793572. 